\title{
Consumer Payment Choice for Bill Payments
}

$2020 \bullet$ No. 20-5

Claire Greene and Joanna Stavins

\begin{abstract}
Why do U.S. consumers pay their bills the way they do? Using data from a recent diary of consumer payment behavior, we find that the type of bill consumers are paying and how they are paying (online or automatically) are important factors in determining the payment method, in addition to the dollar value of the bill and the demographic and income profile of the individual who is paying. In contrast, dollar value and demographic attributes are found to be the most important factors determining the payment instrument chosen for purchases. Consumer choices for bill payments are somewhat constrained by requirements imposed by merchants, while the choice of payment instrument for purchases is not constrained by such requirements.
\end{abstract}

The convenience and speed provided by automatic and online payments are not benefitting all U.S. consumers equally. Unbanked consumers lack access to most payment methods and, hence, use cash or prepaid cards to pay their bills. Low-income consumers pay their bills differently from the rest of the sample: they are more likely to pay in person, use significantly more cash, and are less likely to set up automated or online bill payments, regardless of whether they have a bank account.

Although consumers specify in the diary which methods they prefer to use to pay their bills, in practice they are not likely to act consistently with their stated preferences. We find that consumers who pay their bills online are less likely to deviate from their preferred payment method, while those who pay their bills automatically are more likely to deviate, after we control for income, demographic attributes, the dollar amount of the bill, and the merchant type. We find no evidence of the salience effect of automatic bill payments that Sexton (2015) finds for energy consumption. Rather, we find that consumers who pay their bills automatically have higher incomes and spend more on bills than lowerincome consumers do, but that automatic bill payments are lower in value on average, which is the opposite of the finding by Sexton (2015).

JEL Classifications: D12, D14, E42

Keywords: bill payments, payment choice, payment preferences, consumer payments

Claire Greene is a payments risk expert with the Federal Reserve Bank of Atlanta's Retail Payments Risk Forum. Her email address is claire.greene@atl.frb.org. Joanna Stavins is a senior economist and policy advisor in the research department at the Federal Reserve Bank of Boston. Her email address is joanna.stavins@bos.frb.org.

This paper presents preliminary analysis and results intended to stimulate discussion and critical comment. The views expressed herein are those of the authors and do not indicate concurrence by the Federal Reserve Bank of Boston, the principals of the Board of Governors, or the Federal Reserve System. This paper, which may be revised, is available on the website of the Federal Reserve Bank of Atlanta at https://www.frbatlanta.org/banking-and-payments/consumerpayments/research-data-reports.

This version: June 2020 


\section{Introduction}

On average, every U.S. consumer spends about $\$ 2,000$ paying bills each month, an amount that represents 58 percent of their total monthly expenditures (2017 Diary of Consumer Payment Choice). ${ }^{1}$ Therefore, understanding which factors affect why they choose to use a particular payment instrument and method is important. To what extent do a consumer's annual household income and demographic attributes affect how they pay their bills, and to what extent are these choices influenced by merchants' bill payment preferences? Using detailed data on individual transactions and on payer attributes, we find that the type of bill a consumer is paying (rent, utilities, telecommunication services, and so on) and how they are paying (online, automatically, and so on) are important factors in determining the chosen payment method, in addition to the dollar amount of the bill and the individual characteristics (demographics and income) of who is paying. Yet consumer attributes explain only some of the decisionmaking process - the payee may require that only certain payment instruments be used, constraining the consumer's set of choices. Bill payments may be recurring or paid automatically and are often paid online, all factors that come into play in the choice of a payment instrument.

The previous literature excludes consumer behavior considerations concerning an important category of bill payments in the United States by focusing primarily on the payment choice for the subset of purchases made at the point of sale (POS), emphasizing the relationship between the payment choice and the transaction value (Arango et al. 2015; Klee 2008; Wakamori and Welte 2017; Wang and Wolman 2016). Bounie and Francois (2011) analyze a wider range of consumer bill payments in France and find that, unlike for POS purchases, consumers do not seem to be sensitive to the transaction costs associated with bill payments and that the transaction amount does not influence the choice of payment instruments. Thus, the typical patterns observed for POS transactions do not hold for consumer bill payment behavior. This paper uses a daily diary survey of payments made by a representative sample of U.S. consumers, combining detailed information about each transaction with a rich set of income and demographic data on the individual consumers making each payment. The data also include information on a consumer's preferred payment instruments, allowing us to observe when consumers act according to their stated preferences and when they deviate from them.

Low-income consumers pay their bills differently from the rest of the sample: they are more likely to pay in person, tend to use more cash, and are less likely to set up automated bill payments or pay using online methods. Unbanked consumers lack access to most types of payment instruments used for remittances and therefore use cash or prepaid cards to pay their bills. Even after we control for individual income and demographic attributes, being unbanked significantly affects consumer payment behavior. We find that merchant acceptance of certain payment methods plays a role in how consumers choose to pay their bills. This finding leads us to conclude that constraints imposed by the payees are

\footnotetext{
${ }^{1}$ The survey is answered by an individual respondent. If the respondent is a member of a household (such as a married couple), they may not be the person paying household bills, but that person's demographic information is the data.
} 
relevant to the choice of a payment instrument used for bills-unlike with purchases, where the preferences of payees have not been found to affect consumers' choice of payment instrument. ${ }^{2}$

The remainder of this paper is organized as follows. Section 2 describes the data used in the analysis. Section 3 describes the characteristics of bill payments that influence U.S. consumer behavior in regard to making these payments. Section 4 estimates the effect of various factors on payment instrument choice for bill payments. Section 5 focuses on low-income and unbanked consumers. Section 6 compares consumers' actual use of payment instruments to their stated preferences. Section 7 models and estimates factors that affect the choice to deviate from a preferred method for paying bills. Section 8 concludes.

\section{Data}

We use data from the 2017 Diary of Consumer Payment Choice (DCPC), a representative survey of U.S. adults conducted by the Federal Reserve Banks of Atlanta, Boston, Richmond, and San Francisco. The 2017 DCPC includes responses from 2,793 individuals with detailed transaction-level data on 14,685 total transactions, including payments, transfers, deposits, and cash withdrawals. Of these 14,685 transactions, 12,118 were payments, including retail POS purchases conducted in person and online, bill payments, and person-to-person payments. Each respondent filled out the diary for three consecutive days during the month of October 2017. For each transaction conducted during the specified three-day period, respondents recorded the date and time, the dollar value, the payment instrument used, the type of merchant (that is, payee or purpose), whether the payment was made in person or remotely, and whether a device, such as a mobile phone or computer, was used. Our analysis also uses banking status data obtained from the Survey of Consumer Payment Choice (SCPC). The SCPC collects data from the same set of respondents as the DCPC and gathers detailed information about their bank account holdings.

Payment instruments include paper-based methods (cash, check, money order), cards (credit card, debit card, prepaid card), and methods that usually are effected through an automated clearinghouse (ACH) transfer. The diary's consumer-facing descriptions of methods that are usually enacted via ACH transfers include (1) an online banking bill payment (OBBP), where the consumer uses the bank's website or mobile banking application (app) to pay a bill, and the bank then originates an $\mathrm{ACH}$ transfer or cuts a paper check and mails it to the merchant/payee; (2) a bank account number payment (BANP), where the consumer enters the bank routing number and their account number at a third-party website-for example, an electric company-to make a bill payment that is deducted directly from the bank account; and (3) an account-to-account transfer (A2A), where the payment is moved from one financial account owned by the consumer to another account, for example, a mortgage payment made from a checking

\footnotetext{
${ }^{2}$ Recently, merchants started experimenting with cashless stores, which would limit consumer choices of payment methods.
} 
account directly to the consumer's mortgage loan account servicer. For purposes of this analysis, an A2A transfer is classified as a BANP because a bank account number is used to effect such a transfer. PayPal also is included as a payment instrument choice; however for purposes of this analysis, PayPal payments are reclassified according to the underlying payment instrument: a card payment, $\mathrm{ACH}$ account transfer, or funds stored at PayPal. ${ }^{3}$

For some transactions, the consumer does not interpret the payment instrument as a financial institution might interpret it. For example, when a consumer pays a bill online through their bank's website or mobile app, the bank most likely settles the payment electronically via an ACH transaction, but it also could mail a paper check. Because our main data source is a consumer payment diary, such a transaction would be classified as an OBBP (not a paper check payment) because that is how the consumer initiates the transaction. So the payment method refers to the instrument used by the consumer, regardless of how the financial institution executes the transaction.

In the DCPC, respondents identify "bills" in two ways: by selecting the bill type from a list of 22 choices (mortgage, rent, tuition, credit card, and so on) or by responding "yes" to a follow-up question - "Was this payment a bill payment?"-included in the daily reporting module for all payments reported (except those in categories typically associated with purchases). ${ }^{4}$ Diary respondents also report whether a bill was paid by automatic payment, which the questionnaire describes as follows: "An automatic bill payment is a payment set up to occur on a pre-scheduled basis. Once set up, it does not require any additional effort on the consumer's part." Follow-up questions probe whether bills are paid on a repeat basis and, if so, their frequency.

Before reporting their individual transactions, DCPC participants take a survey in which they report their preferred method for paying bills and why they prefer it. Respondents select their answer from the following reasons: security, accepted at lots of places, cost, convenience, budget control, rewards, speed, payment records, and getting and setting up billing and payments. Respondents also may write in a reason for favoring a particular payment type. If they use a payment method other than the one they specified as preferred for a given transaction, they are asked why they did not use their preferred method.

The data also include detailed demographic, income, banking status, and employment information for every respondent. ${ }^{5}$ Appendix table 1 shows the percentage share of bills paid by demographic cohorts in the sample. The three-day diary format complicates the comparison of the prevalence of a certain

${ }^{3} \mathrm{~A}$ follow-up question asks respondents how their PayPal payments are funded.

${ }^{4}$ Consumers did not receive the follow-up question "Was this payment a bill payment?" when reporting that they paid the following types of merchants: grocery stores; convenience stores; gas stations; sit-down restaurants and bars; fast-food restaurants; coffee shops, cafeterias and food trucks; general merchandise stores; department stores; other stores; and online stores.

${ }^{5}$ For more details on the 2017 DCPC, see Greene and Stavins (2018). 
behavior-in this case, bill payment-between different consumer cohorts. That is, these results may not be a good estimate of the U.S. population as a whole, because actions such as paying bills may not be spread out equally across the month. As Appendix table 1 shows, the distribution of respondents by demographic characteristics differs from the distribution of bill payments associated with respondents who possess particular characteristics. Therefore, demographic information will be included in the models below and are omitted from the discussion of descriptive statistics in Section 3 (below).

\section{Consumer behavior and bill payment characteristics}

Many factors characterize consumer bill payment behavior. We group them into five major categories: (1) payment instrument use, (2) the dollar value associated with the transaction, (3) automatic/nonautomatic payments, (4) the payment channel, and (5) the payee or purpose. For each category, we emphasize how consumers' bill payment choices differ from those made, or the methods used, for retail purchases.

\section{Payment instrument use}

When paying their bills, consumers use the entire range of payment instruments available to them. Paper checks, BANP, and OBBP are the three most common payment methods. Of these, none is the clear first-choice for consumer bill payments. As shown in table 1, each of the three methods accounts for about 20 percent of all consumer bill payments: 21.0 percent for OBBP, 19.6 percent for BANP, and 19.1 percent for check. The next-most-popular ways to pay bills are by debit card (15.1 percent) and cash (12.3 percent).

Forty percent of bills are paid via electronic means that usually result in an $\mathrm{ACH}$ transaction (BANP or OBBP), 33 percent are paid with paper instruments (cash, check, and money order), and almost 25 percent are paid with cards (credit, debit, and prepaid). This bill payment behavior differs markedly from how consumers use payment instruments to make purchases, conduct which is fairly homogeneous and centered on cards and cash: 93 percent of purchases are paid by cash and cards (credit, debit, and prepaid).

\section{Dollar value}

The mean dollar value of all bills paid was $\$ 248$, and the median value was $\$ 105$, as shown in table 2 . The mean dollar value of a transaction varies with the payment instrument, as is shown in previous research on point-of-sale purchases (Stavins 2018; Klee 2008). For cash transactions, the mean value was $\$ 100$, and the median was $\$ 45$, the lowest values among all payment instruments. In contrast, the mean and median values for bill payments made by check were more than three times higher than for

\footnotetext{
${ }^{6}$ As noted above, the exception to an ACH transaction would be if the bank sends a paper check for a payment initiated via an OBBP. This would occur for small-sized payees that are not equipped to accept electronic $\mathrm{ACH}$ transactions, for example, a local chiropractor or a small landlord.
} 
bills paid in cash: $\$ 333$ and $\$ 150$, respectively. The mean and median values of bill payments made electronically were almost as high as those for bills paid by check. Figure 1 shows the density distribution of the dollar value for cash, check, cards (debit and credit), and electronic bill payments. As the figure demonstrates, bills paid in cash tend to be the lowest in value, followed by cards, while bills paid with checks or electronic payments have the highest dollar value.

Looking at the distribution of bill payments by the dollar amount, shown in the bottom row of table 2, 45 percent of bills paid were for less than $\$ 100,36$ percent of bills ranged from $\$ 100$ to $\$ 299$, and 19 percent of bills were for amounts greater than $\$ 300$. Cash is used most commonly to pay bills less than $\$ 100$, compared with the use of cash for bills in larger dollar amounts. The opposite is true for electronic payments, where the share of bills paid electronically steadily increases with the dollar value. Electronic payments (BANP and OBBP) are used for the majority of bills that are more than $\$ 300$, representing approximately 56 percent of these large-value bills. Paper checks also are a popular instrument for paying high-dollar-value bills, representing 25 percent of all bill payments in this category. Cards and cash are used infrequently for high-dollar-value bills.

Electronic payments also are used frequently for bills ranging from $\$ 100$ to $\$ 299$ : About 41 percent of bills in this category are paid electronically. While checks also remain popular (22 percent), a greater share of bills ranging from $\$ 100$ to $\$ 299$ are paid by cards: 27 percent. For bills less than $\$ 100$, the payment instrument choices are more mixed: Thirty-five percent are paid electronically, 26 percent by cards, and 19 percent by cash.

In Section 4, we estimate the effect that the dollar value of the transaction has on payment instrument choice, controlling for consumer characteristics and merchant type.

\section{Automatic/Nonautomatic payment}

Bills can be paid automatically. As noted above, "an automatic bill payment is a payment set up to occur on a pre-scheduled basis. Once set up, it does not require any additional effort on the consumer's part." As shown in table 3, about 25 percent of all bills are paid automatically; 62 percent of automatic bills are paid electronically using BANP or OBBP, as shown in table 1. Of the bills not paid automatically, 42 percent are paid with a paper method (cash, check, or money order) and 34 percent are paid electronically.

\section{Payment channel}

Bills can be paid online, by mail, in person, or by phone. As shown in table 3, about two-thirds of bills are paid online; the remainder are paid by mail, in person, or by landline phone (table 3 ). Bills paid via certain channels are, by design, constrained in terms of the payment instruments that may be used. For example, cash cannot be used to make online payments.

As one might expect, the payment instruments used for bill payments vary by channel. As shown in table 1, paper methods are used for 79.5 percent of bills paid by mail or in person, compared with their use for only 33 percent of all bill payments. The majority of online bills are paid electronically using OBBP or BANP: 60 percent. Cards are used for 27.5 percent of all online bill payments. 


\section{Payee or purpose}

A substantial share of bill payments are made for housing, for utilities and telecommunication services, and to repay debt obligations, such as loan payments. The way consumers choose to pay their bills varies with the bill type or payee (or "merchant"). Table 4 shows the share of bills paid using the various payment instruments and by merchant types, while figure 2 depicts these results according to all paperbased instruments, card instruments, and electronic instruments, with a small category for other payment instruments. Figure 2 shows that most credit card, insurance, mortgage, and other loan payments are made by electronic means, using OBBP or BANP. In contrast, about half of all rent payments and almost 60 percent of payments for tuition and childcare are made by paper methods (cash, check, and money order). Cards are used most often to pay for the consumer's entertainment bundle (defined to include telephone, internet, cable or satellite TV, video or music streaming services, and movie theaters) and for health-care bill payments. Appendix table 2 shows the number and percentage of bills and the average dollar amount per bill by merchant category.

\section{What factors affect payment instrument choice?}

As we showed above, several characteristics of bill payments are correlated with payment instrument choice: automatic or non-automatic, online or not online, and the type of bill (mortgage, rent, utilities, and so on). In this section, we model the factors that affect why consumers choose particular instruments for making bill payments, incorporating not only the particular characteristics of the individual bill payment, as discussed above, but also individual consumer attributes (demographics and income). These factors help determine the probability of choosing a particular payment instrument; the probability of paying a bill automatically, including testing whether bills paid automatically have higher dollar values; and the probability of paying a bill online.

\section{Choosing a payment instrument}

To estimate the marginal effect of each factor on the probability of using each individual payment instrument, we estimate a multinomial discrete choice model for payment choice, following Klee (2008). The probability that consumer $i$ chooses payment instrument $k$ for transaction type $j$ is specified as:

$$
\operatorname{Pr}(k=1)=f\left(\text { Amount }_{i j}, \text { DEM }_{i}, \text { INCOME }_{i}, \text { BANKING }_{i}, \text { MERCHANT }_{i j}\right),
$$

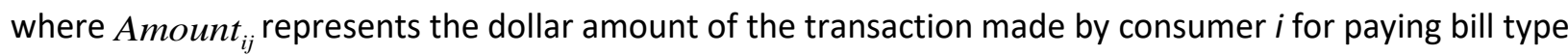
$j$, where $j=\{$ rent, mortgage, utilities, entertainment, credit card, loans, insurance, health care, tuition and childcare, other\}; $D E M_{i}$ is a vector of demographic attributes for consumer $i$ (age, education, gender, race); $I N C O M E_{i}$ is a set of financial variables for consumer $i$, including the household income cohort and employment status; $B A N K I N G_{i}$ is a set of dummy variables describing consumer i's 
banking status (unbanked, underbanked, or fully banked ${ }^{7}$ ); and $M E R C H A N T_{i j}$ is a set of dummy variables equal to 1 if the given bill was paid by consumer $i$ to merchant type $j$ (rent, mortgage, utilities, and so on).

The results from estimating the multinomial logit regression are shown in table $5{ }^{8}$ The numbers in the table depict the marginal effects derived from the estimated coefficients. For continuous variables, the marginal effects are calculated at the mean of each independent variable. For dummy variables, the marginal effects are calculated as the average difference between the probability of using the payment instrument when the dummy variable is set to 1 and when it is set to 0 . For factor variables (merchant type), the marginal effects are calculated as the average difference between a given merchant type and the omitted category of other types of bill payments. The "other" merchant type includes gifts/payments to family members, charitable/religious donations, and general services such as hair dresser, auto repair, and so on

The dollar amount of a bill significantly affects the probability of using particular payment instruments. The larger the dollar value is, the lower the probability of using cash and the higher the probability of using a check or electronic payments, after we control for consumer attributes and bill type.

The payer's demographic attributes also influence the choice of a payment instrument. When we control for the dollar amount and the type of bill, lower-income consumers are more likely to pay their bills in cash compared with the omitted category of consumers in households with incomes over $\$ 100,000$. For consumers with incomes below $\$ 25,000$, the share of cash payments is 15.6 percentage points higher than it is for the omitted high-income group. Lower-income consumers are also significantly less likely to pay their bills by using electronic means (BANP and OBBP). When we control for age and income, more educated consumers are more likely to use credit cards, checks, and electronic payments, but they are less likely to use debit cards. Compared with consumers with a graduate degree, those with some college are 11.5 percent less likely to use credit cards and 12.5 percent less likely to use checks, but they are 21.8 percent more likely to use debit cards. Homeowners are 8.1 percentage points more likely than non-homeowners to use checks and 8.8 percentage points more likely to use credit cards. Even after we control for income and demographics, unbanked consumers pay their bills differently compared with underbanked and fully banked consumers. Section 5

\footnotetext{
${ }^{7}$ In brief, consumers who do not have a checking or savings account are considered unbanked, while those who have a checking or savings account but also used a provider of alternative financial services (AFS, meaning money orders, check cashing services, international remittances, payday loans, refund anticipation loans, pawn shop loans, or auto title loans) during the past 12 months are considered underbanked. Consumers who have a bank account and did not use an AFS during the past 12 months are considered fully banked. Section 5 discusses the implications of banking status in more detail.

${ }^{8} \mathrm{~A}$ property of the multinomial logit model is the "independence of irrelevant alternatives" (IIA), where the relative probability of choosing between two options is independent of any additional alternatives in the choice set. We assume that the IIA holds in this case. For example, if a consumer prefers using a check over using a credit card, adding a debit card as an option would not change their initial preferences.
} 
includes more details about our findings regarding the bill payment choices of low-income and unbanked consumers.

Compared with the "other" category, almost all the main categories of bills are associated with a lower probability of using cash and a higher probability of using electronic payments. Yet rent is 22.1 percent more likely to be paid with a paper check, probably because many landlords require that method of payment (Zhang 2016).

We do not include dummy variables indicating whether a bill is paid automatically or online in the payment instrument choice regressions, since a decision whether to pay a bill automatically or online is not exogenous with respect to the choice of a payment instrument. Below, we estimate the probabilities of paying a bill automatically and online.

\section{Making automatic bill payments}

Do consumers who pay their bills automatically pay a higher dollar amount, on average, after we control for their income and demographic attributes, because they do not see the amount when the bill is paid? Sexton (2015) finds that enrollment in automatic bill payment increased a consumer's residential electricity consumption 4 percent; he attributes the higher spending to a decline in price salience, as consumers tend not to inspect deductions for automatic bill payments.

Sexton's result could be due to sample selection: Consumers who sign up for automatic bill payments have sufficient bank account balances to set up payments in advance and might have higher incomes compared with those consumers who choose to pay each bill when required. In this case, the higher electricity consumption is not a result of making automatic bill payments, but rather due to the practice of consumers who pay higher-value bills choosing to set up automatic bill pay features on their bank accounts.

Bills paid automatically do not have dollar values that are higher than those of bills paid using nonautomatic methods, on average. In fact, the opposite is true: The average value of bills paid automatically is lower than the average value of bills not paid automatically, $\$ 222$ and $\$ 256$, respectively, as shown in table 6 , although the difference is not statistically significant. Looking at a breakdown by income and by education confirms that higher-income consumers and those who are highly educated pay higher-value bills both automatically and non-automatically. Higher-income consumers are also more likely to pay their bills automatically than are lower-income consumers: Whereas consumers with annual incomes below $\$ 25,000$ pay 16 percent of their bills automatically, the share of automatic bill payments rises to 36 percent for those consumers with incomes of $\$ 75,000$ to $\$ 100,000$, and it is 31 percent for those with annual incomes over $\$ 100,000$. This difference in payment behavior explains why consumers who pay their bills automatically may spend more on bills overall. The dollar values also vary across merchant types: Among the bills paid automatically, mortgage and credit card bills have the highest average dollar value, while payments for mortgages, loans, and rent have the highest average dollar value among bills not paid automatically. 
Following up on the above finding, higher-income consumers are more likely to have a higher opportunity cost of time and are less likely to be liquidity constrained compared with lower-income consumers. Therefore, we expect that higher-income consumers are more likely to set up their bills to be paid automatically, so that they do not have to actively pay their bills each month. We further test this hypothesis by estimating the effect that income has on the probability of a bill being paid automatically, controlling for the dollar value, merchant type, banking status, and demographics:

$$
\operatorname{Pr}\left(\text { Automatic }_{i j}\right)=f\left(\text { Amount }_{i j}, \text { DEM }_{i}, \text { INCOME }_{i}, \text { BANKING }_{i}, \text { MERCHANT }_{i j}\right) .
$$

Even after we control for the dollar amount and merchant type associated with each transaction, higher-income consumers are more likely to pay their bills automatically; see table 7, left column. Compared with a consumer with an annual household income over $\$ 100,000$, a person with an annual income below $\$ 25,000$ is 14 percent less likely to pay a bill automatically, while a person with an annual income of $\$ 25,000$ to $\$ 50,000$ is 7 percent less likely to do so. Consumers in these two lower-income groups are less likely to have a financial cushion and are more likely to prefer to pay each bill individually when required. When we control for income and all other demographic factors (age, gender, ethnicity, homeownership, banking status, work status, and job sector), less-educated individuals and black consumers are also less likely to pay automatically. There is some evidence that not paying bills automatically may cost consumers in terms of a higher probability of paying late fees, although the negative correlation between not making automatic bill payments and paying late fees is weak. ${ }^{9}$

Automatic bill payments are also more common for certain merchant types. Mortgage and insurance payments, where the amount of the bill is fixed each time, are more likely to be set up automatically, while utility, healthcare, and credit card bills, where the billing amount varies each time, are less likely to be paid automatically. Hayashi and Klee (2003) report, similarly, that using automatic bill pay (which they call direct bill pay) is positively correlated with frequent and fixed-amount bills.

We did not find support for the hypothesis that, on average, bills paid automatically have a dollar amount greater than that of bills paid actively each time a payment is due. Sexton's (2015) result can be explained not by salience, but rather by the finding that higher-income people are more likely to set up automatic bill pay.

\section{Paying bills online}

As shown in table 3, approximately two-third of all bills are paid online. The average dollar value of bills paid online is almost exactly the same as the amount for bills not paid online (rather, by mail or in person): \$251 and \$247, respectively, which are not statistically different (see table 6). In this

${ }^{9}$ Consumers mostly pay on time; about 15 percent of bills in this sample were paid late, and of those payments, 20 percent triggered a late fee. 
subsection, we estimate the marginal effects of payee and transaction attributes on the probability of paying a bill online:

$$
\operatorname{Pr}\left(\text { Online }_{i j}\right)=f\left(\text { Amount }_{i j}, \text { DEM }_{i}, \text { INCOME }_{i}, \text { BANKING }_{i}, M_{E R C H A N T}\right)_{i j},
$$

where Online $e_{i j}=1$ if consumer $i$ paid bill type $j$ online, and 0 otherwise.

Table 7 (right column) shows the marginal effects that the characteristics of the payee and the transaction have on the probability of making an online payment, based on the regression results. A bill's dollar value has no effect on whether a consumer pays online, after we control for all other consumer and transaction characteristics. Lower-income consumers are significantly less likely to pay online. Compared with a consumer with an annual household income over $\$ 100,000$, a person with an annual household income below $\$ 25,000$ is 12.2 percent less likely to pay a bill online. Men are 6.8 percentage points less likely to pay online than women are. Except for rent, the most common types of bills are significantly more likely to be paid online when compared with the omitted category of "other" bills.

\section{Constraints imposed by payee}

We observe how a consumer pays each bill, but the diary contains little information on the supply-side constraints that might induce the consumer to use a given payment method or prevent them from using another method. Cash cannot be used online, but payees (merchants) might impose additional restrictions on the types of payments they will accept. For example, some merchants impose a minimum dollar value on credit card transactions (a costly payment method for them to accept), post signs trying to discourage customers from using credit cards, or refuse to accept cards. In some cases, merchants apply positive incentives to encourage cash use, such as discounts with cash payments (Stavins 2018).

Although the diary does not provide data on the specific constraints imposed by payees, consumers did specify how they prefer to pay their bills. If their actual method of bill payment deviated from their stated preferences, they were asked for the reasons why they deviated. Below we analyze consumer preferences and the deviations from those stated preferences in detail.

\section{Low-income and unbanked consumers}

We classify consumers based on their banking status using data from the SCPC. Consumers who do not have either a checking or a saving account are classified as unbanked. Following the Federal Deposit Insurance Corporation (FDIC), we classify consumers as "underbanked" if they have a bank account but 
also use some costly nonbank services, a situation that suggests the services offered by their bank are fairly limited. ${ }^{10}$

As shown in table 8, almost 9 percent of U.S. consumers are unbanked, and 23 percent are underbanked. Banking status is highly correlated with income: The average annual household income for unbanked consumers is $\$ 23,510$, compared with $\$ 54,463$ for the underbanked, and $\$ 82,116$ for the fully banked. Unbanked consumers lack most of the payment options available to other consumers. As a result, unbanked consumers pay 81 percent of their bills with cash or prepaid cards. Underbanked consumers have a bank account and thus can access other bill payment methods, but compared with fully banked consumers, the underbanked pay differently: Their share of bills paid in cash is twice as high, while their share of checks and electronic payments is lower. The reason could be that underbanked consumers face a high cost when accessing their bank account (due perhaps to a limit on the number of checks per month or requirements to maintain a minimum balance), whereas fully banked consumers can conduct the same types of transactions without incurring any additional fees.

As noted above, the regression results show that bill payment behavior varies with an individual's income and banking status, even when all other consumer attributes are held constant. Compared with those who are fully banked, unbanked consumers are 40 percentage points more likely to pay cash (table 5), 14.8 percentage points less likely to pay automatically (table 7), and 28.2 percentage points less likely to pay online (table 7), when we control for income. Underbanked consumers also pay their bills differently compared with those who are fully banked, although the differences between the two groups are not as large: The underbanked are 7.3 percentage points more likely to use cash, 10 percentage points less likely to use checks, and 11.4 percentage points more likely to use debit, when we control for income (table 5). Low-income consumers pay their bills differently from the rest of the sample, even when banked: They are more likely to pay in person, use more cash, and are significantly less likely to set up automated bill payments or to pay online. Despite almost universal consumer access to mobile phones in the United States, these data show that convenient and fast electronic, automatic, and online payments are not utilized equally among U.S. consumers.

\section{Consumer preferences for making bill payments}

Above we have discussed how consumers pay their bills and have estimated which factors affect the choice of a payment instrument. Before recording their bill payment behavior in the Diary of Consumer

\footnotetext{
${ }^{10}$ Banking status is defined based on the FDIC's National Survey of Unbanked and Underbanked Households. A consumer is categorized as unbanked if they do not have a checking or savings account. A consumer is categorized as underbanked if they have a checking or savings account and used one of the following products or services from an alternative financial services (AFS) provider in the past 12 months: money orders, check cashing, international remittances, payday loans, refund anticipation loans, rent-to-own services, pawn shop loans, or auto title loans. A consumer is categorized as fully banked if they have a bank account and did not use an AFS in the past 12 months.
} 
Payment Choice, consumers also reported their preferred way to pay bills. In this section, we compare consumers' stated preferences to their actual behavior and estimate what causes them to deviate: payee-introduced constraints; consumer-specific characteristics, such as income or education; or the attributes of the individual transaction, such as the dollar amount.

Like the payment behavior described above, these stated preferences vary markedly across consumers, as shown in table 9. Just half of all U.S. consumers choose one of the top-two preferred payment instruments: OBBP ( 26 percent) and debit card ( 25 percent). In contrast, about 70 percent of consumers choose one of the top-two instruments for making purchases (debit card and credit card). In addition, methods linked to a checking account are popular for bill payments. Together, BANP, check, debit card, and OBBP are the preferred means of paying bills for 75 percent of U.S. consumers. Notably, consumers are unlikely to choose cash as a preferred method for bill pay-only 9 percent of consumers rank cash as their first preference for paying bills.

The survey asked consumers why they ranked particular methods as preferred, but the responses are not especially informative. Overall, 53 percent of consumers cite the catch-all category of "convenience" as the reason for choosing their preferred payment method, regardless of the payment method chosen. Consumers tend to choose convenience as the reason why cash, debit cards, prepaid cards, BANP, OBBP, or money orders (table 10) is their preferred instrument for a bill payment Consumers cite the quality of payment records as the most important reason for using checks and rewards as the most important reason for using credit cards.

Only 46 percent of bills are paid with a consumer's preferred method for paying bills, compared with 60 percent of purchases that are paid for using a consumer's preferred method for purchases. Table 11 shows how consumers' preferred payment methods relate to how they actually pay their bills. For example, consumers who prefer cash use cash for 81.8 percent of their bill payments, so they stay true to their preference more often than is the case for any other payment method. In contrast, consumers who prefer credit cards use that payment method for only 30.9 percent of their bills, paying mainly with paper checks or BANP for the rest of their bills.

As shown in figure 3, 46 percent of the time when consumers do not pay by using their preferred method, their vague reason is: "For this type of bill, I prefer to use [specified non-preferred] method." The next-most-common reason, cited for 11 percent of transactions not paid for with the preferred method, is that the "preferred [method] was not accepted." These vague responses make it difficult to determine with certainty whether the reasons are supply-related (such as acceptance or cost), demandrelated, or both. Below, we estimate the effect of various factors on the probability of deviating from a preferred payment method.

\section{Why do consumers deviate from their stated preferences?}

Consumers might choose to deviate from their stated preferences for making bill payments, or their preferences may vary with the transaction value or with the merchant type. But they could also deviate due to supply-side constraints, such as a lack of acceptance by merchants (the second-most-cited reason 
above) or a fee charged for using cards (mentioned as the reason by a very small number of respondents). As noted above, consumers do not always make it clear in their diary entries whether the reasons for deviating are supply related (such as acceptance or cost) or demand related (such as better record-keeping or security). We investigate the following factors that could be correlated with the probability of deviating from using a preferred payment method:

1. The dollar amount of the bill. Consumers could be more likely to deviate from using a preferred payment method when handling large-dollar or small-dollar transactions.

2. The channels for bill payments, such as online or by mail. Switching associated with the payment channel could be due to constraints. For example, it would be highly unusual to make an inperson bill payment via an ACH method (BANP or OBBP).

3. Whether or not the bill is paid automatically. Switching behavior associated with automatic payments could be due to constraints. For example, it is not possible to make an automatic bill payment by using a paper payment instrument (cash or check).

4. The type of payee (called "merchant" in the model below) or the type of bill, such as rent or mortgage payments. Any deviations associated with bill or payee type could be due to the payee's preferences or limitations. For example, it is not possible to pay a credit card bill or to repay a loan with a credit card, and some landlords require rent to be paid by paper check.

5. The payment instrument. For example, consumers may be less likely to deviate from their preferred method for paying bills if they prefer to use paper checks.

6. Consumer income or demographic attributes. For example, lower-income consumers might be more likely to deviate from using their preferred way to pay because they are liquidity constrained or because their choices are more limited.

We estimate the importance of the above factors on the probability of deviating from stated preferences:

$$
\operatorname{Pr}\left(\text { Deviate }_{i j}\right)=f\left(\text { Amount }_{i j} \text {, Online }_{i j} \text {, Automatic }_{i j}, \text { MERCHANT }_{i j}, \text { PI }_{-} \text {PREFER }_{i k}, \text { DEM }_{i}, \text { INCOME }_{i}\right) \text {, }
$$

where Deviate $e_{i j}$ equals 1 if consumer $i$ deviated from his preferred payment instrument for making bill payments to merchant type $j$, and $P I_{-} P R E F E R_{i k}$ is a set of dummy variables equal to 1 if consumer $i$ prefers using payment instrument $k$.

Table 12 shows the marginal effects of the probability of a consumer deviating from their preferred payment method obtained from a probit regression. The transaction's dollar value does not affect the probability of the consumer deviating from their stated preference. In contrast, the channel for making bill payments is a significant factor: Consumers who pay their bills online are less likely to deviate from their preferred payment method. The use of automatic payment methods also matters: Consumers who 
pay their bills automatically are more likely to deviate from using a preferred payment instrument. ${ }^{11}$ The reason could be that paying online does not impose many limits on a consumer's payment options. Bills can typically be paid with a credit card, a debit card, or with the electronic methods (BANP and OBBP), and a different payment method can be selected separately for each bill. Conversely, automatic bill payments, for which consumers are significantly more likely to deviate, are set up in advance, preventing consumers from actively selecting a payment method each time the bill is paid.

Controlling for the merchant type or for the preferred payment method does not eliminate the effect that making online and automatic bill payments has on the probability of deviating from a preferred payment instrument. Consumers are less likely to deviate from using a favorite instrument when paying bills for utilities, credit cards, or entertainment bundles (see table 12). They are also 23 percent less likely to deviate if their preferred instrument is paper checks, probably because checks can be used for a variety of transactions. However, consumers are 19 percent more likely to deviate from their preferred method if the preferred method is a credit card. As in the dollar amount regressions, very few demographic attributes are significant in the regression.

Of the possible factors affecting the probability of a consumer deviating from their stated preference, we reject numbers 1 and 6 , the explanations related to the dollar amount of the transaction and the consumer's annual household income or demographic information. We find supporting evidence for explanations 2 through 5, those related to the channel used for making bill payments, to whether or not the payment is automatic, to the types of bills or payees, and to the preferred payment instrument.

For some bill payments, consumers may deviate from their stated preference due to supply-side factors, such as constraints or fees imposed by the payees. For example, Zhang (2016) finds that in 2014, 80 percent of U.S. households used paper payment methods to pay rent. Certain entities, including local governments, may impose a surcharge for making card payments, which could lead some consumers to choose a less favored payment method. (For the effect of surcharges and discounts on payment choice for purchases, see Stavins 2018.) And any bill payments made to service a debt cannot be paid with a credit card.

In sum, when determining whether consumers may choose to deviate from their stated preference for which payment instrument to use, most of the payer's demographic characteristics are not significant factors in the decision. The purpose and the payee do have a significant effect, which suggests that the type of transaction (for example, cell phone bill versus rent payment) is much more important than consumer attributes or the bill's dollar amount.

${ }^{11}$ Automatic and online bill payments are not mutually exclusive. Table 3 shows how many types of bill payments can be classified in each category. 


\section{Conclusion}

Consumer bill payment behavior is complex. Despite the availability of electronic technology and account-to-account transfers, bills are often paid with paper payment instruments and cards. This paper analyzes the bill payment behavior of U.S. consumers and how this behavior relates to consumer income and demographic attributes, online or automatic methods of payment, and potential constraints imposed by the payees. This paper also examines cases in which consumers deviate from using their preferred instruments for making bill payments.

Despite the almost universal adoption and use of mobile phones in the United States, convenient and fast electronic, automatic, and online payments are not utilized equally among U.S. consumers. Compared with underbanked or fully banked consumers, unbanked consumers are more likely to pay their bills with cash and are less likely to pay using automatic or online methods. Even when fully banked, low-income consumers pay their bills differently compared with the rest of the sample: They are more likely to pay their bills in person, use cash more frequently, and are significantly less likely to set up automated bill payments or to pay online.

As previous studies find regarding purchase behavior, the dollar value of a bill affects the probability of consumers using particular payment instruments. In contrast to results from previous research, we find that bills paid automatically do not have a higher dollar value when we control for the consumer's annual household income-in fact, utility bills paid automatically have a lower average dollar value than utility bills paid by using other methods. However, we find that people with higher household incomes are more likely to pay their bills using automatic methods.

Our results indicate that merchant preferences or acceptance practices are relevant to determining how consumers choose to pay bills. Consumers are less likely to switch from using a preferred method for making bill payments for certain types of merchants, notably utilities, entertainment, and credit cards. Therefore, we conclude that the supply side (payee) has an important influence on consumers' choice of instruments for paying bills. This incentive effect differs from the choice of a payment instrument used for making purchases, as the individual consumer's demographic information and the transaction amount are the most important factors determining the payment methods used for purchases. 


\section{References}

Arango, Carlos, Kim P. Huynh, and Leonard Sabetti. 2015. "Consumer Payment Choice: Merchant Card Acceptance versus Pricing Incentives." Journal of Banking \& Finance 55(June): 130-141.

Bounie, David, and Francois, Abel. 2011. "The Economics of Bill Payments: An Empirical Analysis." Applied Economics Letters 18(10): 961-966.

Greene, Claire, and Joanna Stavins. 2018. "The 2017 Diary of Consumer Payment Choice." Federal Reserve Bank of Atlanta Research Data Report No. 18-5.

Hayashi, Fumiko, and Elizabeth Klee. 2003. "Technology Adoption and Consumer Payments: Evidence from Survey Data." Review of Network Economics 2(2): 175-190.

Klee, Elizabeth C. 2008. "How People Pay: Evidence from Grocery Store Data." Journal of Monetary Economics 55(3): 526-541.

Sexton, S. 2015. "Automatic Bill Payment and Salience Effects: Evidence from Electricity Consumption." Review of Economics and Statistics 97(2): 229-241.

Stavins, Joanna. 2018. "Consumer Preferences for Payment Methods: Role of Discounts and Surcharges." Journal of Banking \& Finance 94(9): 35-53.

Wakamori, Naoki, and Angelika Welte. 2017. "Why Do Shoppers Use Cash? Evidence from Shopping Diary Data." Journal of Money, Credit and Banking 49(1): 115-169.

Wang, Zhu, and Alexander L. Wolman. 2016. "Payment Choice and the Future of Currency: Insights from Two Billion Retail Transactions." Journal of Monetary Economics 84: 94-115

Zhang, David Hao. 2016. “How Do People Pay Rent?" Federal Reserve Bank of Boston Research Data Reports No. 16-2. 
Table 1: Shares of bill payments by payment instrument and by channel (percentages)

\begin{tabular}{l|ccccc}
\hline \multicolumn{1}{l}{} & All & $\begin{array}{c}\text { Mail/In } \\
\text { Person/Phone }\end{array}$ & Online & Automatic & $\begin{array}{c}\text { Not } \\
\text { Automatic }\end{array}$ \\
\hline Cash & 12.3 & 35.2 & -- & -- & 16.1 \\
Check & 19.1 & 41.0 & 7.4 & 2.2 & 24.4 \\
Money Order & 1.8 & 3.3 & 1.0 & 0.0 & 2.4 \\
\hline & & Cards & & & \\
\hline Credit Card & 8.0 & 4.9 & 9.9 & 16.1 & 5.6 \\
Debit Card & 15.1 & 9.5 & 17.6 & 11.1 & 16.3 \\
Prepaid Card & 0.1 & 0.2 & -- & -- & 0.1 \\
\hline & Electronic Ways to Pay from a Bank Accounts & & 13.6 \\
\hline BANP & 19.6 & 2.3 & 29.2 & 39.6 & 20.2 \\
OBBP & 21.0 & 3.3 & 30.8 & 22.9 & 1.2 \\
\hline Other & & & & & $\mathbf{1 0 0 . 0}$ \\
\hline Total & 2.8 & 0.2 & 4.1 & 8.1 & $\mathbf{1 0 0 . 0}$ \\
\hline
\end{tabular}

Source: 2017 Diary of Consumer Payment Choice

Notes: PayPal payments are classified according to the underlying payment instrument, for example, card or ACH account transfer. Account-to-account transfers (A2A) are classified as BANP payments because a bank account number is used to effect such a transfer. Some columns do not sum up to 100.0 due to rounding. 
Table 2: Mean and median amount and shares of bill payments, by instrument and dollar value

\begin{tabular}{|c|c|c|c|c|c|c|}
\hline & \multirow{2}{*}{$\begin{array}{l}\text { Average } \\
\text { Dollar } \\
\text { Amount }\end{array}$} & \multirow{2}{*}{$\begin{array}{l}\text { Median } \\
\text { Dollar } \\
\text { Amount }\end{array}$} & \multicolumn{4}{|c|}{ Shares of Bills (Percentages) } \\
\hline & & & $<\$ 100$ & $\$ 100-\$ 299$ & $>\$ 300$ & Total \\
\hline Cash & $\$ 100$ & $\$ 45$ & 19.2 & 6.5 & 7.2 & 12.3 \\
\hline Check & $\$ 333$ & $\$ 150$ & 14.9 & 21.6 & 25.4 & 19.1 \\
\hline Money Order & $\$ 219$ & $\$ 49$ & 2.2 & 1.6 & 1.6 & 1.8 \\
\hline Credit Card & $\$ 207$ & $\$ 87$ & 10.0 & 8.1 & 3.3 & 8.0 \\
\hline Debit Card & $\$ 124$ & $\$ 99$ & 16.1 & 18.6 & 3.5 & 15.1 \\
\hline BANP & $\$ 323$ & $\$ 142$ & 16.4 & 17.9 & 31.3 & 19.6 \\
\hline OBBP & $\$ 252$ & $\$ 133$ & 18.7 & 22.6 & 24.5 & 21.0 \\
\hline Other & $\$ 252$ & $\$ 116$ & 2.5 & 3.2 & 3.3 & 2.9 \\
\hline Total & $\$ 248$ & $\$ 105$ & 100.0 & 100.0 & 100.0 & 100.0 \\
\hline $\begin{array}{l}\text { Number of } \\
\text { Observations } \\
\text { (Weighted) }\end{array}$ & 2,173 & 2,173 & 976 & 776 & 420 & 2,173 \\
\hline $\begin{array}{l}\text { Percent of } \\
\text { Observations }\end{array}$ & -- & -- & 45 & 36 & 19 & -- \\
\hline
\end{tabular}

Source: 2017 Diary of Consumer Payment Choice

Notes: "Other" includes prepaid cards, PayPal, account-to-account, income deduction, and other unspecified payments. The total weighted number of bills with non-missing amount information. The numbers might not add up to 100.0 perfectly due to the rounding. 
Table 3: How bills were paid

\begin{tabular}{|l|c|c|c|c|}
\hline & $\begin{array}{c}\text { By Mail, In } \\
\text { Person, By } \\
\text { Phone }\end{array}$ & Online & Total & Percent \\
\hline Automatic & 25 & 477 & 502 & 23 \\
\hline Not Automatic & 743 & 918 & 1661 & 77 \\
\hline Total & 768 & 1395 & 2164 & 100 \\
\hline Percentage & 36 & 64 & 100 & - \\
\hline
\end{tabular}

Source: 2017 Diary of Consumer Payment Choice

Notes: The transactions tabulated in this table have non-missing information on both online and automatic status. 
Table 4: Percentage share of bills by payment instrument and by merchant categories

\begin{tabular}{|c|c|c|c|c|c|c|c|c|c|c|}
\hline \multirow{2}{*}{ Instrument } & \multicolumn{3}{|c|}{ Credit } & \multirow[b]{2}{*}{ Loans } & \multirow[b]{2}{*}{ Utilities } & \multirow[b]{2}{*}{$\begin{array}{l}\text { Entertainment } \\
\text { Bundle }\end{array}$} & \multirow[b]{2}{*}{ Rent } & \multicolumn{3}{|c|}{ Tuition } \\
\hline & Insurance & $\begin{array}{c}\text { Card } \\
\text { Payments }\end{array}$ & Mortgage & & & & & Healthcare & $\begin{array}{c}\text { and } \\
\text { Childcare }\end{array}$ & Other \\
\hline Cash & 2.1 & 1.4 & -- & 2.2 & 13.7 & 8.1 & 9.9 & 13.0 & 29.6 & 27.6 \\
\hline Check & 7.6 & 12.3 & 23.6 & 18.6 & 20.7 & 11.1 & 23.4 & 26.8 & 28.9 & 28.9 \\
\hline Money Order & 1.0 & -- & 0.7 & 3.2 & 1.7 & -- & 15.9 & 0.1 & -- & 2.5 \\
\hline Credit & 3.0 & -- & 7.0 & -- & 3.5 & 14.9 & 14.2 & 29.4 & 2.8 & 8.7 \\
\hline Debit & 7.1 & 8.4 & 6.0 & 14.7 & 14.4 & 26.7 & 14.0 & 15.7 & 34.2 & 11.2 \\
\hline BANP & 49.1 & 36.1 & 51.7 & 40.7 & 12.0 & 17.6 & 10.8 & 9.4 & 3.6 & 5.9 \\
\hline OBBP & 23.6 & 37.9 & 10.9 & 20.0 & 32.7 & 19.9 & 9.3 & 2.6 & 0.0 & 10.5 \\
\hline Other & 6.5 & 3.9 & -- & 0.5 & 1.4 & 1.6 & 2.5 & 3.0 & 0.9 & 4.7 \\
\hline Total & 100.0 & 100.0 & 100.0 & 100.0 & 100.0 & 100.0 & 100.0 & 100.0 & 100.0 & 100.0 \\
\hline
\end{tabular}

Source: 2017 Diary of Consumer Payment Choice

Notes: "Other" instruments include prepaid, PayPal, account-to-account, income deduction, and other unspecified payments. Shading indicates the most popular payment method for each merchant category. Some columns do not sum up to 100.0 due to rounding. 
Table 5: Multinomial logit model of bill payment instrument choice, marginal effects

\begin{tabular}{|c|c|c|c|c|c|c|c|c|c|c|c|c|c|}
\hline \multirow[b]{2}{*}{ Dollar Value } & \multirow[b]{2}{*}{ Amount (Hundreds) } & \multicolumn{2}{|c|}{ Cash } & \multicolumn{2}{|c|}{ Check } & \multicolumn{2}{|c|}{ Credit } & \multicolumn{2}{|c|}{ Debit } & \multicolumn{2}{|c|}{ BANP } & \multicolumn{2}{|c|}{ OBBP } \\
\hline & & -0.023 & $* *$ & 0.013 & $* *$ & 0.003 & & -0.009 & $*$ & 0.008 & $* *$ & 0.006 & * \\
\hline Age & Age & -0.001 & & 0.008 & $* * *$ & -0.001 & & -0.003 & $* *$ & -0.003 & $* *$ & 0.001 & \\
\hline \multirow{5}{*}{ Education } & Less than High School & 0.034 & & -0.080 & & -0.168 & $*$ & 0.318 & $* * *$ & -0.092 & $*$ & -0.004 & \\
\hline & High School & 0.031 & & -0.024 & & -0.097 & $*$ & 0.112 & $* *$ & -0.055 & & -0.061 & $*$ \\
\hline & Some College & -0.013 & & -0.125 & $* *$ & -0.115 & $*$ & 0.218 & $* * *$ & -0.048 & & 0.019 & \\
\hline & College & 0.019 & & -0.049 & & -0.067 & & 0.040 & & -0.040 & & 0.012 & \\
\hline & Graduate & - & - & - & - & - & - & - & - & - & - & - & - \\
\hline \multirow[t]{2}{*}{ Gender } & Male & 0.011 & & 0.015 & & 0.038 & & -0.010 & & -0.023 & & -0.027 & * \\
\hline & Female & - & - & - & - & - & - & - & - & - & - & - & - \\
\hline \multirow{5}{*}{ Income } & Less than $\$ 25,000$ & 0.156 & $* *$ & 0.010 & & -0.068 & & 0.064 & & -0.072 & * & -0.062 & * \\
\hline & $\$ 25,000-\$ 49,999$ & 0.080 & $*$ & 0.008 & & -0.056 & & 0.071 & $* *$ & -0.051 & * & -0.045 & * \\
\hline & $\$ 50,000-\$ 74,999$ & 0.036 & & 0.009 & & -0.073 & & 0.045 & & 0.008 & & -0.016 & \\
\hline & $\$ 75,000-\$ 99,999$ & -0.028 & & -0.028 & & 0.000 & & 0.070 & $*$ & 0.034 & & -0.046 & $*$ \\
\hline & More than $\$ 100,000$ & - & - & - & - & - & - & - & - & - & - & - & - \\
\hline \multirow[t]{2}{*}{ Ethnicity } & Latino & 0.031 & & -0.009 & & -0.086 & & 0.004 & & 0.049 & & -0.036 & \\
\hline & Non-Latino & - & - & - & - & - & - & - & - & - & - & - & - \\
\hline \multirow{4}{*}{ Race } & Black & 0.043 & & -0.074 & & -0.052 & & 0.030 & & 0.047 & & -0.102 & $* *$ \\
\hline & Asian & 0.013 & & -0.101 & & 0.208 & $*$ & -0.055 & $*$ & -0.117 & $* *$ & -0.014 & \\
\hline & Other & -0.048 & & -0.280 & $* * *$ & -0.168 & * & 0.204 & & 0.251 & & -0.135 & $* *$ \\
\hline & White & - & - & - & - & - & - & - & - & - & - & - & - \\
\hline \multirow[t]{2}{*}{ Homeownership } & Homeowner & -0.046 & $*$ & 0.081 & $*$ & 0.088 & $*$ & -0.025 & & -0.067 & $* *$ & -0.005 & \\
\hline & Non-homeowner & - & - & - & - & - & - & - & - & - & - & - & - \\
\hline \multirow{3}{*}{ Work Status } & Employed & 0.003 & & 0.009 & & -0.083 & & -0.050 & * & 0.060 & & 0.065 & \\
\hline & Not in the Labor Force & 0.009 & & -0.080 & & -0.099 & & -0.056 & $*$ & 0.120 & * & 0.089 & * \\
\hline & Unemployed & - & - & - & - & - & - & - & - & - & - & - & - \\
\hline \multirow[t]{2}{*}{ Job Sector } & Work for Government & -0.007 & & -0.014 & & -0.027 & & 0.005 & & -0.002 & & 0.048 & $*$ \\
\hline & Other Sectors & - & - & - & - & - & - & - & - & - & - & - & - \\
\hline Banking & Unbanked & 0.399 & $* * *$ & -0.232 & $* * *$ & 0.024 & & -0.032 & & -0.169 & $* * *$ & -0.083 & $* *$ \\
\hline \multirow[t]{2}{*}{ Status } & Underbanked & 0.073 & $*$ & -0.100 & $* * *$ & 0.004 & & 0.114 & $* * *$ & -0.038 & & -0.057 & $* *$ \\
\hline & Fully Banked & - & - & - & - & - & - & - & - & - & - & - & - \\
\hline \multirow{10}{*}{ Merchant } & Rent & -0.056 & $*$ & 0.221 & $* * *$ & -0.102 & & -0.059 & $*$ & 0.024 & & -0.011 & \\
\hline & Mortgage & -0.091 & $*$ & -0.114 & $*$ & -0.151 & $*$ & -0.065 & $* *$ & 0.407 & $* * *$ & 0.059 & \\
\hline & Utilities & -0.073 & $* *$ & -0.068 & & -0.090 & $*$ & -0.034 & & 0.071 & & 0.231 & $* * *$ \\
\hline & Entertainment Bundle & -0.086 & $*$ & -0.179 & $* * *$ & 0.101 & $*$ & 0.015 & & 0.111 & $* *$ & 0.080 & $*$ \\
\hline & Credit Card Bills & -0.086 & $*$ & -0.184 & $* * *$ & -0.168 & $*$ & -0.053 & $* *$ & 0.253 & $* * *$ & 0.260 & $* * *$ \\
\hline & Loans & -0.084 & $*$ & -0.099 & & -0.168 & $*$ & -0.055 & $*$ & 0.257 & $* * *$ & 0.183 & $* *$ \\
\hline & Insurance & -0.082 & $*$ & -0.211 & $* * *$ & -0.116 & $*$ & -0.057 & $* *$ & 0.360 & $* * *$ & 0.112 & $*$ \\
\hline & Healthcare & -0.058 & $*$ & -0.036 & & 0.352 & $* * *$ & 0.013 & & -0.152 & $* * *$ & -0.089 & $* *$ \\
\hline & Tuition and Childcare & -0.045 & & 0.187 & $*$ & -0.069 & & 0.053 & & -0.010 & & -0.096 & $*$ \\
\hline & Other & - & - & - & - & - & - & - & - & - & - & - & - \\
\hline \multicolumn{2}{|l|}{ Pseudo R-squared } & \multicolumn{12}{|c|}{0.2090} \\
\hline \multicolumn{2}{|c|}{ Number of Observations } & & & & & & & & & & & & \\
\hline
\end{tabular}

Source: 2017 Diary of Consumer Payment Choice

Notes: ${ }^{* *}$ significant at $1 \%,{ }^{* *}$ significant at $5 \%, *$ significant at $10 \%$. Reference group marked as “-”. For continuous variables, the marginal effects are calculated at the means of the independent variables in the case of continuous variables. For dummy variables, the marginal effects are calculated as the average difference between the probability of using the payment instrument of the dummy variable set to one and set to zero. 
Table 6: Percentage of bills paid automatically/online and the average dollar amount, by demographics, income, and merchant type

\begin{tabular}{|c|c|c|c|c|c|c|c|}
\hline & & \multirow{2}{*}{$\begin{array}{c}\text { Percent of } \\
\text { Bills Paid } \\
\text { Automatically }\end{array}$} & \multicolumn{2}{|c|}{ Average Dollar Value } & \multirow{2}{*}{$\begin{array}{l}\text { Percent of } \\
\text { Bills Paid } \\
\text { Online }\end{array}$} & \multicolumn{2}{|c|}{ Average Dollar Value } \\
\hline & & & $\begin{array}{c}\text { Automatic } \\
\text { Bills } \\
\text { (\$) }\end{array}$ & $\begin{array}{c}\text { Non- } \\
\text { automatic } \\
\text { Bills (\$) }\end{array}$ & & $\begin{array}{l}\text { Online } \\
\text { Bills } \\
\text { (\$) }\end{array}$ & $\begin{array}{c}\text { Non- } \\
\text { online Bills } \\
\text { (\$) }\end{array}$ \\
\hline \multirow[t]{3}{*}{ Total } & & 26 & 222 & 256 & 67 & 251 & 247 \\
\hline & Under 25 & 8 & 70 & 109 & 63 & 128 & 76 \\
\hline & $25-34$ & 29 & 327 & 305 & 69 & 282 & 355 \\
\hline \multirow[t]{6}{*}{ Age } & $35-44$ & 30 & 202 & 278 & 73 & 271 & 223 \\
\hline & $45-54$ & 26 & 146 & 217 & 71 & 217 & 168 \\
\hline & $55-64$ & 23 & 172 & 236 & 65 & 252 & 158 \\
\hline & Over 64 & 27 & 253 & 261 & 63 & 242 & 278 \\
\hline & Less than High School & 10 & 61 & 158 & 49 & 140 & 148 \\
\hline & High School & 21 & 164 & 152 & 60 & 162 & 143 \\
\hline \multirow[t]{3}{*}{ Education } & Some College & 26 & 197 & 233 & 70 & 169 & 372 \\
\hline & College & 28 & 191 & 274 & 69 & 271 & 209 \\
\hline & Graduate & 31 & 384 & 483 & 70 & 423 & 532 \\
\hline \multirow[t]{4}{*}{ Gender } & Male & 27 & 216 & 294 & 64 & 272 & 284 \\
\hline & Female & 25 & 231 & 212 & 70 & 226 & 200 \\
\hline & Less than $\$ 25,000$ & 16 & 145 & 133 & 55 & 157 & 114 \\
\hline & $\$ 25,000-\$ 49,999$ & 23 & 173 & 196 & 66 & 208 & 163 \\
\hline \multirow[t]{3}{*}{ Income } & $\$ 50,000-\$ 74,999$ & 26 & 165 & 216 & 70 & 205 & 202 \\
\hline & $\$ 75,000-\$ 99,999$ & 36 & 316 & 386 & 71 & 327 & 425 \\
\hline & More than $\$ 100,000$ & 31 & 262 & 380 & 71 & 322 & 428 \\
\hline \multirow[t]{2}{*}{ Ethnicity } & Latino & 28 & 288 & 174 & 67 & 205 & 192 \\
\hline & Non-Latino & 26 & 217 & 262 & 67 & 254 & 251 \\
\hline \multirow{4}{*}{ Race } & White & 27 & 220 & 275 & 68 & 260 & 270 \\
\hline & Black & 17 & 215 & 143 & 60 & 180 & 127 \\
\hline & Asian & 25 & 352 & 255 & 78 & 263 & 308 \\
\hline & Other & 13 & 115 & 94 & 41 & 92 & 73 \\
\hline Home & Homeowner & 27 & 227 & 276 & 68 & 277 & 241 \\
\hline Ownership & Non-homeowner & 25 & 208 & 213 & 64 & 180 & 257 \\
\hline Working & Employed & 26 & 244 & 278 & 71 & 267 & 285 \\
\hline \multirow[t]{2}{*}{ Status } & Unemployed & 13 & 35 & 132 & 52 & 165 & 89 \\
\hline & Not in the Labor Force & 28 & 207 & 251 & 63 & 232 & 249 \\
\hline Banking & Unbanked & 9 & 91 & 101 & 34 & 123 & 83 \\
\hline \multirow[t]{6}{*}{ Status } & Underbanked & 25 & 289 & 147 & 61 & 206 & 142 \\
\hline & Fully Banked & 28 & 214 & 309 & 71 & 270 & 328 \\
\hline & Rent & 21 & 420 & 488 & 49 & 321 & 744 \\
\hline & Mortgage & 39 & 847 & 885 & 76 & 975 & 431 \\
\hline & Utilities & 18 & 92 & 117 & 68 & 122 & 95 \\
\hline & Entertainment Bundle & 33 & 91 & 133 & 81 & 125 & 106 \\
\hline Merchant & Credit Card Bills & 14 & 802 & 388 & 85 & 429 & 493 \\
\hline \multirow[t]{5}{*}{ Category } & Loans & 28 & 303 & 501 & 73 & 467 & 418 \\
\hline & Insurance & 66 & 149 & 200 & 82 & 138 & 290 \\
\hline & Healthcare & 8 & 68 & 102 & 39 & 111 & 93 \\
\hline & Tuition and Childcare & 23 & 310 & 104 & 36 & 184 & 109 \\
\hline & Other & 26 & 138 & 291 & 43 & 215 & 289 \\
\hline
\end{tabular}

Source: 2017 Diary of Consumer Payment Choice 
Table 7: Probability of paying a bill automatically or online, marginal effects

\begin{tabular}{|c|c|c|c|c|c|}
\hline \multirow[b]{2}{*}{ Dollar amount } & \multirow[b]{2}{*}{ Amount } & \multicolumn{2}{|c|}{ Paying Automatically } & \multicolumn{2}{|c|}{ Paying Online } \\
\hline & & 0.000 & & 0.000 & \\
\hline Age & Age & -0.004 & $* * *$ & -0.003 & $* * *$ \\
\hline \multirow{5}{*}{ Education } & Less than High School & -0.161 & $* * *$ & -0.105 & \\
\hline & High School & -0.061 & $*$ & -0.057 & \\
\hline & Some College & -0.035 & & 0.021 & \\
\hline & College & -0.015 & & -0.025 & \\
\hline & Graduate & - & 一 & - & - \\
\hline \multirow[t]{2}{*}{ Gender } & Male & 0.017 & & -0.068 & $* * *$ \\
\hline & Female & - & - & - & - \\
\hline \multirow{5}{*}{ Income } & Less than $\$ 25,000$ & -0.142 & $* * *$ & -0.122 & $* * *$ \\
\hline & $\$ 25,000-\$ 49,999$ & -0.072 & $* * *$ & -0.045 & \\
\hline & $\$ 50,000-\$ 74,999$ & -0.050 & $*$ & -0.005 & \\
\hline & $\$ 75,000-\$ 99,999$ & 0.061 & $*$ & -0.023 & \\
\hline & More than $\$ 100,000$ & - & - & - & - \\
\hline \multirow[t]{2}{*}{ Ethnicity } & Latino & 0.018 & & -0.008 & \\
\hline & Non-Latino & - & 一 & - & - \\
\hline \multirow{4}{*}{ Race } & Black & -0.105 & $* * *$ & -0.013 & \\
\hline & Asian & 0.021 & & 0.095 & $*$ \\
\hline & Other & -0.031 & & -0.070 & \\
\hline & White & - & - & - & - \\
\hline Home & Homeowner & -0.026 & & -0.016 & 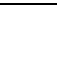 \\
\hline Ownership & Non-homeowner & - & - & - & - \\
\hline \multirow{3}{*}{ Work Status } & Employed & 0.072 & & 0.049 & \\
\hline & Not in the Labor Force & 0.212 & $* * *$ & 0.078 & \\
\hline & Unemployed & - & - & - & - \\
\hline \multirow[t]{2}{*}{ Job Sector } & Work for Government & -0.012 & & -0.003 & \\
\hline & Other Sectors & - & - & - & - \\
\hline \multirow[t]{3}{*}{ Banking Status } & Unbanked & -0.148 & $* * *$ & -0.282 & $* * *$ \\
\hline & Underbanked & 0.010 & & -0.078 & $* * *$ \\
\hline & Fully Banked & - & - & - & 一 \\
\hline \multirow{10}{*}{ Merchant } & Rent & -0.009 & & 0.086 & \\
\hline & Mortgage & 0.134 & $* *$ & 0.309 & $* * *$ \\
\hline & Utilities & -0.082 & $* * *$ & 0.264 & $* * *$ \\
\hline & Entertainment Bundle & 0.071 & $* *$ & 0.390 & $* * *$ \\
\hline & Credit Card Bills & -0.142 & $* * *$ & 0.401 & $* * *$ \\
\hline & Loans & 0.011 & & 0.285 & $* * *$ \\
\hline & Insurance & 0.443 & $* * *$ & 0.394 & $* * *$ \\
\hline & Healthcare & -0.188 & $* * *$ & -0.043 & \\
\hline & Tuition and Childcare & -0.110 & & -0.140 & \\
\hline & Other & - & 一 & - & 一 \\
\hline Pseudo R-squared & & 0.1270 & & 0.1430 & \\
\hline Number of Observations & & 2,437 & & 2,416 & \\
\hline
\end{tabular}

Source: 2017 Diary of Consumer Payment Choice

Notes: $* * *$ significant at $1 \%, * *$ significant at $5 \%$, * significant at $10 \%$. Reference group marked as "—". 
Table 8: Average shares of bills paid with each payment instrument, by banking status

\begin{tabular}{|c|c|c|c|c|c|c|c|c|c|c|c|}
\hline Banking Status & $\begin{array}{l}\text { Percent of } \\
\text { Consumers }\end{array}$ & $\begin{array}{l}\text { Annual } \\
\text { Income }\end{array}$ & Cash & Check & Credit & Debit & Prepaid & BANP & OBBP & $\begin{array}{c}\text { Money } \\
\text { order }\end{array}$ & $\begin{array}{c}\text { Income } \\
\text { Deduction }\end{array}$ \\
\hline Unbanked & 8.97 & $\$ 23,510$ & 55.23 & 0.00 & 6.79 & 0.00 & 25.94 & 0.00 & 0.00 & 9.48 & 2.56 \\
\hline Underbanked & 23.33 & $\$ 54,463$ & 10.43 & 6.45 & 10.64 & 36.29 & 2.48 & 19.43 & 7.32 & 3.32 & 3.64 \\
\hline Fully Banked & 67.50 & $\$ 82,116$ & 5.80 & 12.07 & 18.71 & 20.93 & 1.06 & 24.92 & 14.28 & 0.00 & 2.23 \\
\hline
\end{tabular}

Source: 2018 Survey of Consumer Payment Choice

Notes:

(1) Banking status is defined based on the Federal Deposit Insurance Corporation (FDIC) National Survey of Unbanked and Underbanked Households. A consumer is categorized as unbanked if they did not have a checking or savings account. A consumer is categorized as underbanked if they had a checking or savings account and used one of the following products or services from an alternative financial services (AFS) provider in the past 12 months: money orders, check cashing, international remittances, payday loans, refund anticipation loans, rent-to-own services, pawn shop loans, or auto title loans. A consumer is categorized as fully banked if they had a bank account and did not use AFS in the past 12 months.

(2) Shading indicates the highest share for each banking status. For example, unbanked consumers pay 55.23 percent of their bills in cash, on average. 
Table 9: Percentage of consumers selecting each payment instrument as preferred method for paying bills and making purchases, ranked in descending order of the percentage selected as the preferred instrument for bill payments

\begin{tabular}{l|cc}
\hline & Bills & Purchases \\
\hline OBBP & 26.4 & 0.6 \\
Debit Card & 24.7 & 41.7 \\
Check & 13.6 & 1.5 \\
Credit Card & 11.9 & 28.9 \\
BANP & 9.9 & 0.3 \\
Cash & 8.9 & 24.2 \\
Prepaid/Gift/EBT Card & 1.4 & 1.4 \\
Money Order & 1.1 & 0.3 \\
Account-to-Account Transfer & 0.7 & 0.0 \\
PayPal & 0.2 & 0.8 \\
Other & 1.0 & 0.2 \\
\hline
\end{tabular}

Source: 2017 Diary of Consumer Payment Choice

Notes: Some columns do not sum up to 100.0 due to rounding. 
Table 10: Most important characteristic of the preferred bill payment instrument, by the percentage of consumers who prefer each payment instrument

\begin{tabular}{|c|c|c|c|c|c|c|c|c|c|c|}
\hline Characteristics & Cash & Check & Credit & Debit & Prepaid & BANP & OBBP & $\begin{array}{l}\text { Money } \\
\text { Order }\end{array}$ & PayPal & $\begin{array}{l}\text { Account- } \\
\text { to } \\
\text { Account }\end{array}$ \\
\hline Acceptance & 13.1 & 3.5 & 6.8 & 12.8 & 6.2 & 2.5 & 1.1 & 15.3 & -- & -- \\
\hline Budget & 7.5 & 11.7 & 1.8 & 5.3 & 11.2 & 5.7 & 2.0 & 1.6 & -- & 2.7 \\
\hline Convenience & 49.7 & 24.4 & 30.5 & 52.6 & 57.3 & 63.0 & 75.7 & 47.6 & 4.3 & 79.9 \\
\hline Cost & 3.8 & 1.2 & 2.0 & 0.9 & 4.0 & 2.1 & 0.2 & 7.9 & -- & -- \\
\hline Setup & 0.2 & 0.8 & -- & 0.1 & -- & 1.9 & 0.2 & -- & -- & -- \\
\hline Records & 0.8 & 42.0 & 3.0 & 7.1 & 6.2 & 5.3 & 6.0 & 9.5 & -- & 4.5 \\
\hline Rewards & -- & -- & 39.9 & 0.3 & -- & -- & -- & -- & -- & -- \\
\hline Security & 5.8 & 12.1 & 12.2 & 7.4 & 13.8 & 14.0 & 8.8 & 17.4 & 50.7 & -- \\
\hline Speed & 14.9 & 1.4 & 2.3 & 13.1 & 1.2 & 3.2 & 4.7 & -- & 45.0 & 12.9 \\
\hline Other & 4.2 & 2.9 & 1.5 & 0.4 & -- & 2.4 & 1.2 & 0.8 & -- & -- \\
\hline Total & 100.0 & 100.0 & 100.0 & 100.0 & 100.0 & 100.0 & 100.0 & 100.0 & 100.0 & 100.0 \\
\hline
\end{tabular}

Source: 2017 Diary of Consumer Payment Choice

Notes: The shading indicates the characteristic with the highest percentage of consumers who prefer each payment instrument. For example, among those consumers who prefer credit cards, 39.9 percent selected rewards as the most important characteristic associated with that payment instrument. Some columns do not sum up to 100.0 due to rounding. 
Table 11: Percentage shares of payment instrument use by preferred bill payment instrument

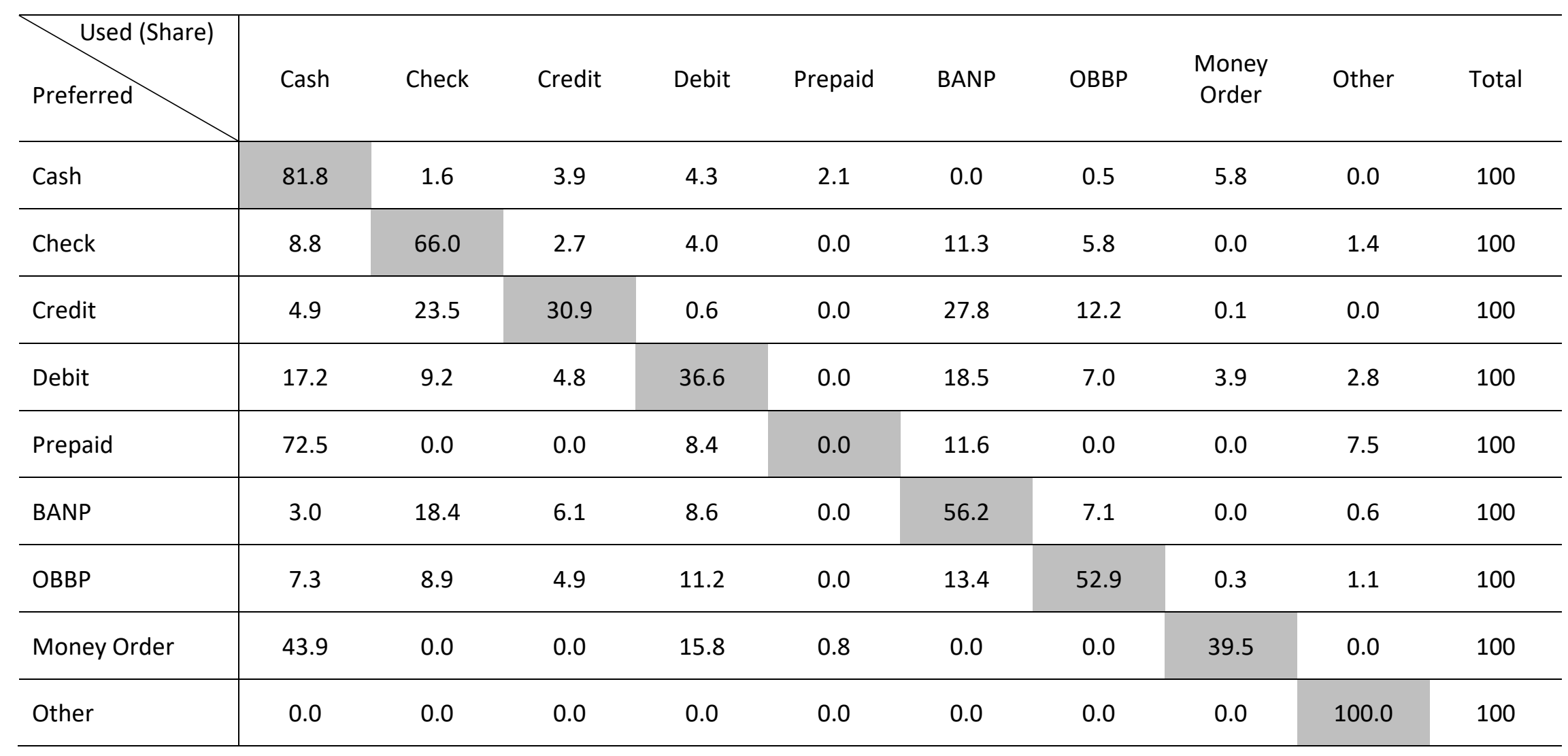

Source: 2017 Diary of Consumer Payment Choice

Notes: The numbers on the diagonal show the percentage of consumers who use the same payment instrument they indicated as their preferred method. For example, 81.8 percent of bill payments made by people who prefer cash were actually paid in cash, while 4.3 percent of those bill payments were paid by debit card. Some rows do not sum up to 100.0 due to rounding. 
Table 12: Probability of deviating from a/the preferred instrument for bill payment, marginal effects

\begin{tabular}{|c|c|c|c|}
\hline & & Deviation & \\
\hline Dollar Amount & Amount & 0.000 & \\
\hline \multirow[t]{2}{*}{ Bill Location } & Online & -0.171 & $* * *$ \\
\hline & Not Online & - & - \\
\hline \multirow[t]{2}{*}{ Bill Type } & Automatic Bill & 0.138 & $* * *$ \\
\hline & Non-automatic Bill & - & 一 \\
\hline Age & Age & 0.001 & \\
\hline \multirow{5}{*}{ Education } & Less than High School & -0.179 & $* *$ \\
\hline & High School & -0.017 & \\
\hline & Some College & -0.022 & \\
\hline & College & -0.022 & \\
\hline & Graduate & - & - \\
\hline \multirow[t]{2}{*}{ Gender } & Male & 0.012 & \\
\hline & Female & - & - \\
\hline \multirow{5}{*}{ Income } & Less than $\$ 25,000$ & 0.073 & $*$ \\
\hline & $\$ 25,000-\$ 49,999$ & 0.053 & \\
\hline & $\$ 50,000-\$ 74,999$ & 0.027 & \\
\hline & $\$ 75,000-\$ 99,999$ & 0.019 & \\
\hline & More than $\$ 100,000$ & - & - \\
\hline \multirow[t]{2}{*}{ Ethnicity } & Latino & 0.145 & $* * *$ \\
\hline & Non-Latino & - & - \\
\hline \multirow{4}{*}{ Race } & Black & 0.076 & $*$ \\
\hline & Asian & 0.016 & \\
\hline & Other & -0.292 & $* * *$ \\
\hline & White & - & - \\
\hline Home & Homeowner & 0.042 & \\
\hline Ownership & Non-homeowner & - & - \\
\hline \multirow{3}{*}{ Work Status } & Employed & 0.048 & \\
\hline & Not in the Labor Force & 0.102 & $*$ \\
\hline & Unemployed & - & - \\
\hline \multirow[t]{2}{*}{ Job Sector } & Work for Government & -0.023 & \\
\hline & Other Sectors & - & - \\
\hline \multirow[t]{3}{*}{ Banking Status } & Unbanked & -0.109 & \\
\hline & Underbanked & 0.027 & \\
\hline & Fully Banked & - & 一 \\
\hline \multirow{10}{*}{ Merchant } & Rent & 0.028 & \\
\hline & Mortgage & -0.057 & \\
\hline & Utilities & -0.192 & $* * *$ \\
\hline & Entertainment Bundle & -0.231 & $* * *$ \\
\hline & Credit Card Bills & -0.158 & $* * *$ \\
\hline & Loans & -0.044 & \\
\hline & Insurance & -0.063 & \\
\hline & Healthcare & -0.018 & \\
\hline & Tuition and Childcare & -0.043 & \\
\hline & Other & - & 一 \\
\hline \multirow{5}{*}{$\begin{array}{l}\text { Instrument } \\
\text { Preference }\end{array}$} & Prefer Check & -0.230 & $* * *$ \\
\hline & Prefer Credit & 0.192 & $* * *$ \\
\hline & Prefer Debit & 0.081 & \\
\hline & Prefer BANP & -0.089 & \\
\hline & Prefer $O B B P$ & -0.045 & \\
\hline Pseudo R-squared & & 0.1000 & \\
\hline Number of Observations & & 2,332 & \\
\hline
\end{tabular}

Source: 2017 Diary of Consumer Payment Choice

Notes: ${ }^{* *}$ significant at $1 \%,{ }^{* *}$ significant at $5 \%$, * significant at $10 \%$. Reference group marked as "—". 
Figure 1: Distribution of bill payment amount, by payment instrument

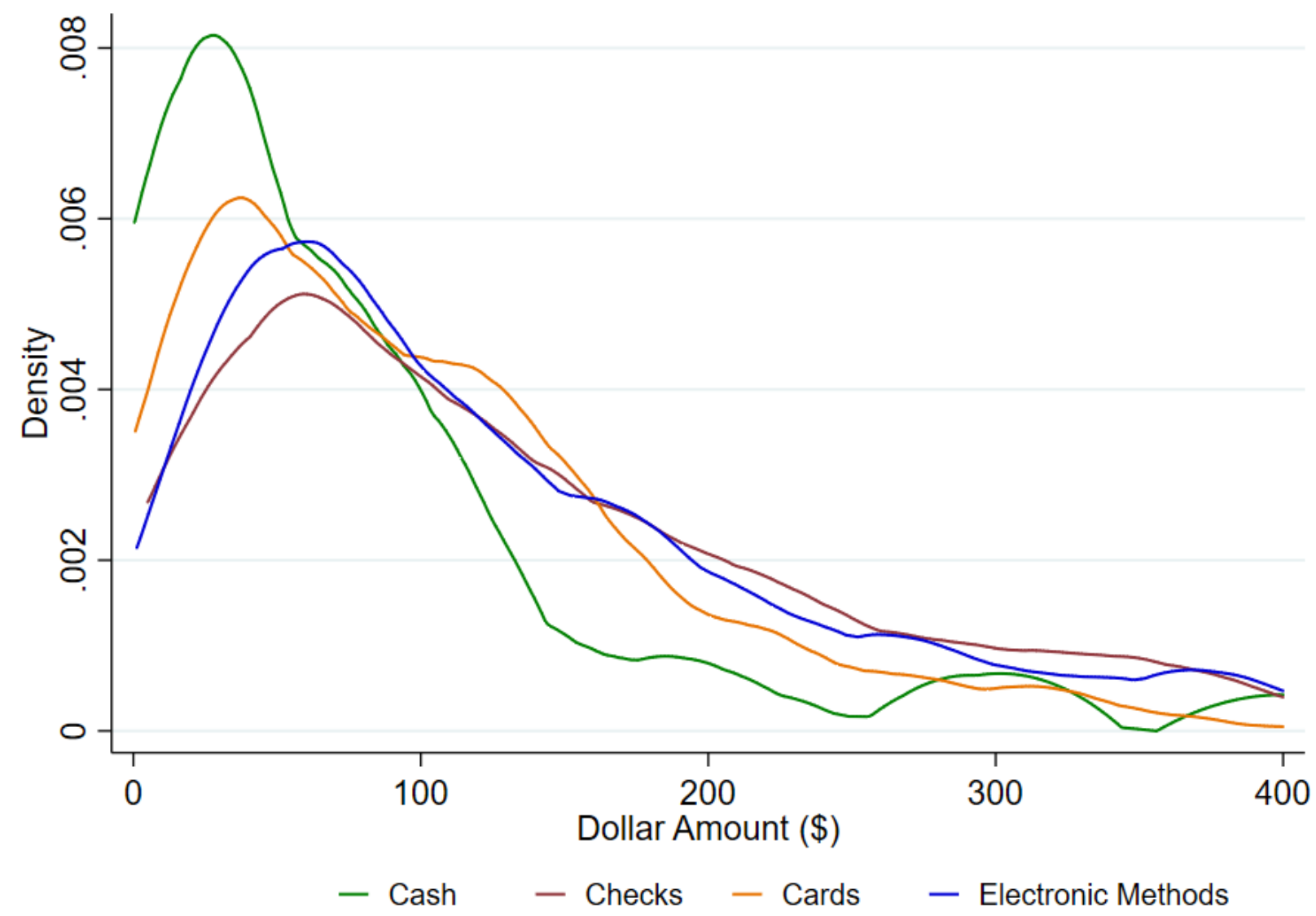

Source: 2017 Diary of Consumer Payment Choice 
Figure 2: Transaction shares of payment instruments by merchant (payee) type, ranked by the percentage of shares paid electronically

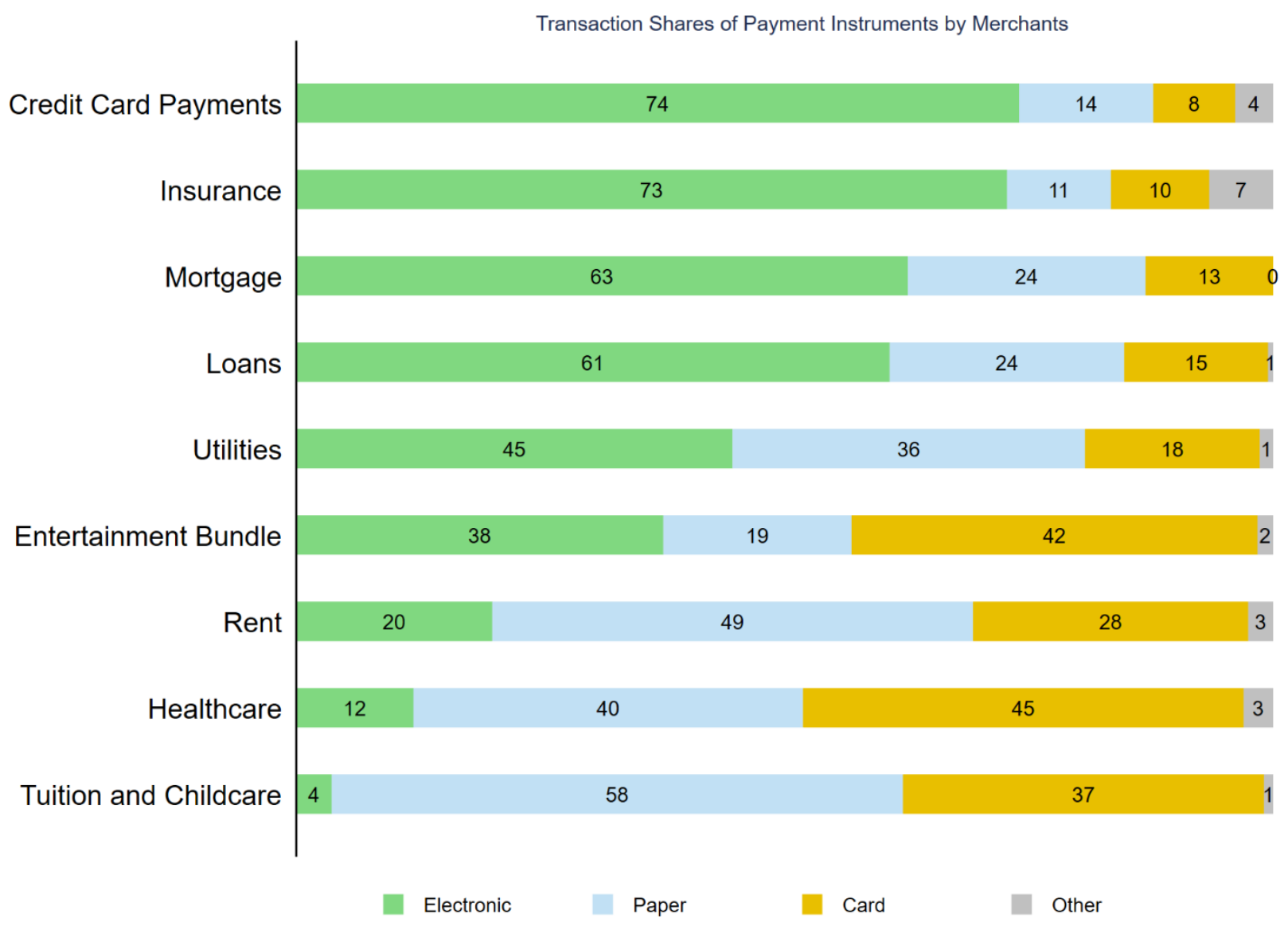

Source: 2017 Diary of Consumer Payment Choice

Notes: Throughout this report, mortgage and other loan payments classified by the survey respondent as an accountto-account transfer have been reclassified as bank account number payments, as the bank account number is used to effect such transfers. "Other" includes PayPal, account-to-account, income deduction, and other unspecified payments. 
Figure 3: Reasons for deviating from preferred bill payment method, ranked by percentage

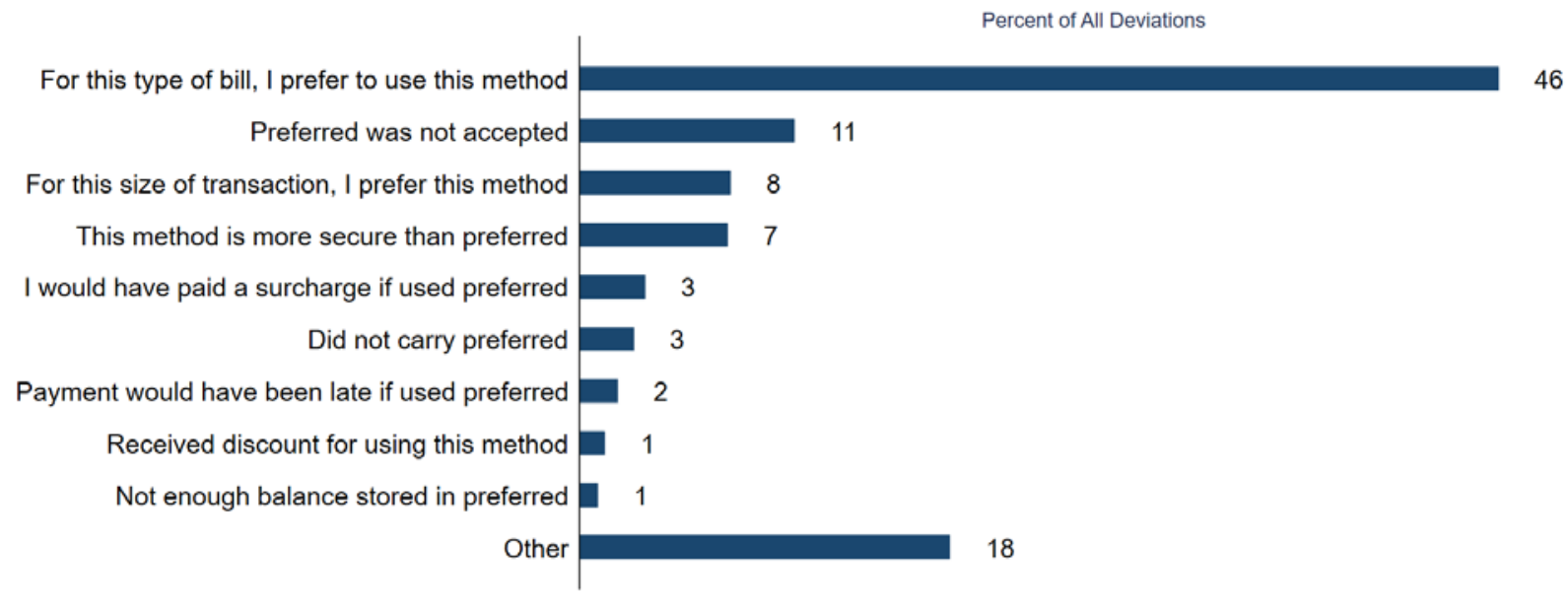

Source: 2017 Diary of Consumer Payment Choice 
Appendix

Appendix table 1: Percentage share of respondents and bill payments by demographic category

\begin{tabular}{|c|c|c|c|}
\hline & & $\begin{array}{l}\text { Percentage } \\
\text { Share of } \\
\text { Respondents }\end{array}$ & $\begin{array}{l}\text { Percentage of } \\
\text { Bill Payments }\end{array}$ \\
\hline & Under 25 & 3 & 1 \\
\hline & $25-34$ & 15 & 12 \\
\hline \multirow[t]{6}{*}{ Age } & $35-44$ & 20 & 17 \\
\hline & $45-54$ & 18 & 19 \\
\hline & $55-64$ & 24 & 26 \\
\hline & Over 64 & 20 & 26 \\
\hline & Less than High School & 5 & 3 \\
\hline & High School & 20 & 17 \\
\hline \multirow[t]{3}{*}{ Education } & Some College & 23 & 21 \\
\hline & College & 36 & 41 \\
\hline & Graduate & 17 & 18 \\
\hline \multirow[t]{4}{*}{ Gender } & Male & 43 & 46 \\
\hline & Female & 57 & 54 \\
\hline & Less than $\$ 25,000$ & 19 & 16 \\
\hline & $\$ 25,000-\$ 49,999$ & 24 & 23 \\
\hline \multirow[t]{3}{*}{ Income } & $\$ 50,000-\$ 74,999$ & 20 & 22 \\
\hline & $\$ 75,000-\$ 99,999$ & 14 & 14 \\
\hline & More than $\$ 100,000$ & 23 & 25 \\
\hline \multirow[t]{3}{*}{ Ethnicity } & Latino & 6 & 6 \\
\hline & Non-Latino & 94 & 94 \\
\hline & White & 87 & 88 \\
\hline \multirow[t]{3}{*}{ Race } & Black & 10 & 9 \\
\hline & Asian & 3 & 3 \\
\hline & Other & 1 & 1 \\
\hline Home & Homeowner & 71 & 77 \\
\hline Ownership & Non-homeowner & 29 & 23 \\
\hline Working & Employed & 60 & 61 \\
\hline \multirow[t]{2}{*}{ Status } & Unemployed & 6 & 4 \\
\hline & Not in the Labor Force & 34 & 35 \\
\hline Banking & Unbanked & 7 & 3 \\
\hline \multirow[t]{2}{*}{ Status } & Underbanked & 22 & 23 \\
\hline & Fully Banked & 70 & 74 \\
\hline Total & & 100 & 100 \\
\hline
\end{tabular}

Source: 2017 Diary of Consumer Payment Choice

Notes: The numbers are unweighted. Percent of sample adds up to 100 within each demographic category. The numbers might not add up to 100 perfectly due to the rounding. 
Appendix table 2: Number of bills and the average dollar amount by merchant categories, ranked as a percentage share of all bills

\begin{tabular}{|c|c|c|c|}
\hline & $\begin{array}{c}\text { Weighted } \\
\text { Number of Bills }\end{array}$ & $\begin{array}{c}\% \text { Share of All } \\
\text { Bills }\end{array}$ & $\begin{array}{c}\text { Average } \$ \\
\text { Amount per Bill }\end{array}$ \\
\hline Entertainment Bundle & 413 & 19 & $\$ 122$ \\
\hline Utilities & 389 & 18 & $\$ 113$ \\
\hline Credit Card Payment & 328 & 15 & $\$ 437$ \\
\hline Insurance & 144 & 7 & $\$ 161$ \\
\hline $\begin{array}{l}\text { Healthcare Institution or } \\
\text { Professional }\end{array}$ & 108 & 5 & $\$ 100$ \\
\hline Loans & 101 & 5 & $\$ 453$ \\
\hline Rent & 100 & 5 & $\$ 470$ \\
\hline Tuition and Childcare & 60 & 3 & $\$ 118$ \\
\hline Mortgage & 53 & 2 & $\$ 887$ \\
\hline Other ${ }^{(1)}$ & 489 & 22 & $\$ 258$ \\
\hline Total & $2,185^{(2)}$ & 100 & $\$ 248$ \\
\hline
\end{tabular}

Source: 2017 Diary of Consumer Payment Choice Notes:

(1) The top three categories in "Other" are: a gift or repayment to a family member, friend, co-worker or someone who did a small job for you; charitable or religious donations; general services (haircare, auto repair, parking lots, laundry or dry cleaning). "Other" also includes merchant categories typically associated with purchases, such as grocery stores and restaurants.

(2) Total weighted number of bills with non-missing merchant category information. 